\title{
ANALYSIS OF THE SIGNIFICANCE OF EWOM ON SOCIAL MEDIA FOR COMPANIES
}

\author{
David Prantl, Michal Mičík
}

\section{Introduction}

The importance of social media has risen significantly in recent years. The use of social media results in a competitive advantage for companies, thanks to which they can strengthen their relationship with customers (Vendemia 2017; Nacimento \& Silveria, 2017; Eger, Mičík, \& Řehoř, 2018). Social media can be defined as on-line applications that allow people to share information and learn from others (Wilson, 2010).

Companies are very active on social media. They manage their profiles, invest in advertising and communicate with customers. However, only a small part of online communication about the company is in the hands of the particular company (Huete-Alcocer, 2017). A large percentage of online posts about companies is created directly by users and spread by electronic word of mouth - eWOM (Brown et al., 2007). Such content is referred to as usergenerated content. The advantages of usergenerated content are pointed out by Geurin and Burch (2017) as well as by Marine-Roig and Clavé (2015), according to whom this type of content is more effective (it will result in a more long-term relationship with customers) than content created by the company itself. Users mention companies in their posts, share them and add various comments to them. These can either be positive or negative (Yang, 2017).

Part of the communication between users on social media is private (conducted through messages between users), but part can be found on public profiles. This type of communication on social media provides us with enough data to analyze and evaluate its significance for the companies. Very few research studies have pointed out the major advantages of such data analyses (Li et al., 2017; Ruan, Durresi, \& Alfantoukh, 2018; Nguyen et al., 2015). The subject of this research article is the analysis of public posts on social media sites. The primary objective of our analysis is to evaluate the significance of posts on social media for the largest joint-stock companies in the world. In case of positive results, the research could be extended on other joint-stock companies that use social media.

The paper is organized as follows: first part presents the existing work in the area, second part presents our proposed methods to address the research questions and third part shows the results of our research. Finally, the conclusions are given.

\section{Literature Review}

Social media have changed the model of communication between companies and their customers. Their arrival has resulted in an increase in the importance of so-called buzz marketing, which Hughes (2005) defines as causing excitement among customers and the media with the aim of customers and the media spreading the original advertising message themselves. Carl (2006) identifies with this view and points out that buzz marketing utilizes the decades-old concept of word of mouth (WOM).

One of the first definitions of WOM was put forth by Katz and Lazarsfeld (1966), who define this term as the exchange of marketing information among consumers in such a way that it influences their behavior and attitude to products and services. Kotler and Keller (2013) define WOM as the verbal spreading of information about a particular product among friends, family and colleagues. Litvin et al. (2008) further state that it is important for those who spread the message to be viewed as independent of the company the message is about. Consumers generally trust other consumers more than the actual seller (Nieto et al., 2014). The advertising message is not spread solely by the company, but primarily 
by customers. The company only creates the message and gives the initial impulse for its spread. This way companies can significantly reduce their advertising costs and invest more in further developing their brand.

The basic pre-requisite for successful WOM is trust (Nieto et al., 2014; Choi \& Lee, 2017). Nieto et al. (2014) also noticed that in recent years people's trust has increasingly spread to the online environment. While in the past people trusted most their loved ones, nowadays they also trust posts by strangers on the Internet. Drucker (1992) notes that trust is the basis of all commercial transactions and relationships. The measure of trust between individuals is defined mainly by benevolence, ability and integrity (Colquitt, Scott, \& LePine, 2007; Mayer, Davis, \& Schoorman, 1995). Integrity is defined as being fair, just and honoring one's promises (whether the person does what they say they will do). Benevolence is understood as willingness to help others. Ability refers to one's skills and competence. An important pre-requisite for WOM is independence from the given company, which gives the person spreading the message credibility (Brown et al., 2007; Lee \& Youn, 2009). If the influencer is affiliated with the given company, it is impossible to expect integrity from them and the level of trust is lower. Subsequently, the more we trust the messenger, the greater the impact of WOM on users.

The degree to which people trust various types of content on social media is the focus of the research study by Choi and Lee (2017). They divide online content into that generated by users and that created directly by companies. They also differentiate between cognitive and affective (emotional) trust. Affective trust is based mainly on the emotional bond, while cognitive trust is based primarily on one's confidence in the ability and integrity of another person. The research results indicate that user-generated content has a higher share of cognitive trust compared to content created directly by companies. In terms of affective trust, it is exactly the opposite.

WOM is considered to be one of the most important factors in deciding on whether to purchase a particular product (Daugherty \& Hoffman, 2014; Litvin et al., 2008). Also companies themselves are aware of the importance of WOM, and thus have to focus more on building a good name for themselves and creating quality products (Hussain et al., 2017).

The major differences between word of mouth on the Internet and in real life are noted by Brown et al. (2007) and Huete-Alcocer (2017). While in the real world the quality of the message relayed is judged by the person we received the message from, the quality of messages on social media sites is influenced by a number of factors (mainly the particular website and other people in the community). Word of mouth in the digital environment is also for that reason referred to as eWOM. The main differences between WOM and eWOM according to Huete-Alcocer (2017) are shown in Tab. 1. The low level of privacy in eWOM can be utilized in analyzing how users speak about a selected company on social media.

Yang (2017) points out the potential disadvantages of eWOM for companies. In the case of negative opinions being spread, companies have no way of controlling the spread

\section{Tab. 1: Differences between WOM and eWOM}

\begin{tabular}{l|l|l} 
& \multicolumn{1}{|c|}{ WOM } & \multicolumn{1}{c}{ eWOM } \\
\hline Credibility & $\begin{array}{l}\text { The recipient knows the messenger } \\
\text { (positive effect on credibility). }\end{array}$ & $\begin{array}{l}\text { Anonymity between the messenger and } \\
\text { the recipient of the information (negative } \\
\text { effect on credibility). }\end{array}$ \\
\hline Privacy & $\begin{array}{l}\text { The conversation is private, interpersonal } \\
\text { and takes place in real time. }\end{array}$ & $\begin{array}{l}\text { The information shared is not private }- \text { it } \\
\text { comes in written form and can be viewed } \\
\text { or shown to another person at any time. }\end{array}$ \\
\hline Transfer speed & $\begin{array}{l}\text { The message spreads slowly. Users must } \\
\text { be present when the information is being } \\
\text { shared. }\end{array}$ & $\begin{array}{l}\text { The message spreads very quickly } \\
\text { among users. }\end{array}$ \\
\hline
\end{tabular}


of negative eWOM, which can significantly reduce the company's revenue. To reduce this risk, it is advisable that companies create their own website through which users can submit their grievances (Huete-Alcocer, 2017).

\subsection{The Effect of Using Social Media on the Business}

In literature, the effect of social media on companies is most frequently evaluated from two points of view - in terms of the impact on the company's financial indicators and in terms of the effect on customer satisfaction or shopping behavior.

\section{The Effect on Financial Indicators}

$\mathrm{Li}$ et al. (2017) examined the possibility of predicting the development of a particular company's stock prices based on the sentiment of posts about the given company on Twitter. They determined the sentiment of 200 million posts mentioning companies listed on US stock markets. Using these data, they were able to predict the future development of their stock prices with $70 \%$ accuracy.

The correlation between the sentiment of Twitter posts and the development of the stock prices of eight American companies was examined by Ruan, Durresi and Alfantoukh (2018). They examined a total of more than 150,000 posts. In addition to evaluating the sentiment of each post, in their model they also included the assessment of the post's credibility based on its author. Their research study shows that the stock prices of the given companies can be better predicted using these data. It also shows that taking into consideration the authors' credibility improves the final results.

The sentiment of online posts about selected companies listed on the stock market was the subject of a study by Nguyen et al. (2015). They found that stock prices can be better predicted according to what people say about the company on the Internet rather than based on their past development. Similar results were confirmed in a research study by Oliveira et al. (2017), who claim that data obtained from social media are very beneficial in predicting stock prices mainly because they are available in real time and their acquisition is not very costly.

Using various financial indicators, the impact of using social media on a company's performance is evaluated by Kim et al.
(2015), who conducted their research among restaurants in the USA. The financial indicators used for the purpose of the study included, for example, ROA, assets and Tobin's Q. Of the KPIs examined, ROA exhibited the lowest correlation. Their research results indicate that the successful use of social media goes hand in hand with the size of the company, its turnover and Tobin's $Q$ indicator, which evaluates the company's market value on the stock market. A study by Kaushik (2017) contradicts these conclusions and considers the effect of social media on a company's value as insignificant. However, in Kaushik's research the use of social media is evaluated based mainly on the number of followers of the given profile and the number of posts uploaded to these profiles per month. However, unlike in other research studies, Kaushik's research did not take into account the quality of the posts.

The importance of social media in the British hotel industry is the focus of a research study by Tajvidi and Karami (2017), who gathered data from a total of 384 hotels (with up to 250 employees). Their research results indicate a positive and significant correlation between the use of social media and the company's performance (in terms of growth and profitability).

\section{The Effect on Customer Satisfaction and Shopping Behavior}

The actual advantages of word of mouth are pointed out by Duan et al. (2008). Based on analyses of users' shopping behavior, they found that word of mouth affects people's shopping behavior and positive word of mouth leads to higher sales. Nieto et al. (2014) show that there is a direct link between positive reviews and the company's performance. Companies that are praised by users on social media have a higher turnover. The factors that influence successful spreading among users are the subject of a study by Wang et al. (2016), who found that people most frequently share messages that they can identify with and that are innovative.

Customers' relationships with companies based on social media are evaluated by Vendemia (2017), whose research proves that well-managed communication with customers on social media increases their willingness to make a purchase from the particular company. The utilization of social media is also positively 
evaluated by Yadav and Rahman (2017), who examined the effect of the use of social media in online shopping. Their research proves that utilizing social media raises people's awareness of the brand, increases customer satisfaction and the willingness to make a purchase from the particular company. Similar results were also reached by Godey et al. (2016), whose research focused on customers of luxury fashion brands (Dior, Gucci, Louis Vuitton, etc.).

Grizane and Jurgelane (2017) deal with an evaluation of the impact of using social media. In their study, they assess the impact of social media use by the five largest restaurants in the Latvian city of Jelgava. The impact is examined primarily based on a questionnaire survey conducted among the restaurants' owners and employees. The study proves the positive effect of social media on the restaurants' business. The correlation between the level of satisfaction among small shop owners in Thailand with their business results and their use of social media was worked out by Charoensukmongkol and Sasatanun (2017). They found a significant correlation between the two and confirmed that using social media does have a positive effect on the business. They also note that the effect of using social media on the business depends on the target customer group. Social media are important mainly in industries that target people who are very active on social media (e.g., young people). Broeck et al., 2018 are also in agreement with this statement.

The impact of social media on small and medium-sized businesses is evaluated using in-depth interviews by Wang et al. (2016). In their study, they focus mainly on communication in the B2C sector and based on interviews with employees they arrived at the conclusion that social media improve the effectiveness of communication (it is faster, there is higher employee satisfaction, and the results achieved are better).

Most research studies agree that social media do have an impact on companies' performance and play a significant role in communication with customers. However, very few studies deal directly with evaluating the significance of social media posts generated by users themselves. The studies listed often do not differentiate between user-generated content and that created by companies themselves, although the majority of the content posted to social media sites is generated by their users. A number of studies also emphasize that user-generated content has a much greater effect on shopping behavior than content created by companies (Brown et al., 2007; Lee \& Youn, 2009). In this research study we try to take a slightly different approach. Instead of determining significance that social media have on company's performance, we are trying discover whether social media can reflect company's performance. There are many factors that effect changes of stock prices, in this paper we examine whether these changes are reflected on social media. If the relationship between social media posts and change in stock prices exists, one look at social media would suffice to determine a company's performance.

\section{Methodology}

In the paper we will be focusing on usergenerated content posted to social media and spread by eWOM. The objective of our analysis is to evaluate the significance of these posts for companies and shareholders in terms of marketing communication. To achieve this objective, given existing knowledge, the following research questions were formulated:

1. Can eWOM serve as an indicator of companies' performance, measured in terms of stock-value change?

2. How much of companies' website traffic is routed through eWOM on social media sites?

3. Through which social media sites does eWOM attract the most traffic to companies' websites?

To address the above-mentioned research question 1, the two hypotheses were developed and tested in this study. The hypotheses were formulated as follows:

H1: B2C companies with a higher share of positive posts have a higher average difference in stock prices than B2C companies with a lower share of positive posts.

H2: B2B companies with a higher share of positive posts have a higher average difference in stock prices than $B 2 B$ companies with a lower share of positive posts.

To answer these three research questions, we used a quantitative approach. The research included 30 global companies, some of the largest in the world. These global companies are those associated with the US30 stock market index (aka Dow Jones Industrial 
Average), which includes the largest and most traded companies in the USA (SPIndices.com, 2019). This index was established as early as in 1896 (it included 12 companies at the time) and is calculated as a price-weighted average (with more weight assigned to stocks with a higher price). For the purpose of this research, we focused on the companies that are components of the US30 stock market index. These are successful companies that employ millions of people.

For purposes of finding the answer to $R Q 1$, we have monitored differences in the stock prices and share of positive posts compared to negative ones over one year, i.e. April 1, 2018 - March 30, 2019. The period was divided into 4 quartiles (Q2 2018, Q3 2018, Q4 2018, $Q 12019)$. To answer $R Q 2$ and $R Q 3$, we have monitored website traffic in the same period, i. e. April 1, 2018 - March 30, 2019.

It's crucial for these companies to have a good image, which ensures a money supply from shareholders as well as the sale of their products. Our research deals with social media posts about these companies spread by users of social media sites through eWOM and the effect of social media on the traffic on these companies' websites. A total of $1,420,000$ Facebook and Twitter posts about these companies acquired from April 1, 2018 to March 30, 2019 was examined. The posts were downloaded using the Unamo.com (2019) tool. Tab. 2 contains a list of the companies, including the aforementioned indicators. For the purpose of our analysis, we divided the companies based on which segment they mostly operate in - B2B or B2C. The analysis shows that the companies' results as well as the industries in which they operate differ, thus capturing well the market development.

\subsection{Analyses Conducted}

To answer the research questions, we will conduct the following analyses:

Analysis 1) Can eWOM serve as an indicator of companies' performance, measured in terms of stock-value change? To answer this question, we will examine whether any changes in the value of stocks are correlated with the positive-to-negative posts ratio on social media. We will determine whether companies with falling stock prices have a higher share of negative posts on social media sites, and on the other hand, whether companies with rising stock prices in the given period have a higher share of positive posts.

The evaluation of the posts' sentiment will be done based on words appearing in them. Based on this analysis, we will divide the posts into two categories - positive and negative ones. Posts containing ambiguous sentiments will be eliminated from the analysis. The analysis will be conducted using the machine learning equipped tool Unamo.com (Coombs, 2018). Using machine learning, the posts downloaded via the API of individual social media will be divided into positive and negative ones based on words contained in them. The tool uses the Naive Bayes classifier to carry out the analysis. For each word in the post, its sentiment will be evaluated based on a dictionary and subsequently the conditioned probability of either a positive or negative sentiment of the post as a whole will be determined.

The sample of companies will be sorted according to the share of positive posts to negative ones and divided into two equally large sets (given the number of companies). The first set will contain half of the companies that demonstrated a relatively higher share of positive posts compared to negative ones on social media. The other set will be comprised of companies with a higher share of negative posts compared to the first set. The first set will thus include companies of which people speak mostly positively on social media, while the other set will be made up of companies of which people speak mostly negatively (relatively within the sample examined). For both sets of companies, we will calculate the percentage difference in their stock prices. Subsequently, we will examine whether there is any significant statistical difference in these values between the two sets of companies.

To determine the statistical significance, we will conduct the t-test (Sedlačík, 2016). First, using the F-test, we will determine the equality of variances $(s)$ in both sets. We will establish the zero hypothesis $H_{0}: s_{1}{ }^{2}=S_{2}{ }^{2}$ and the alternative hypothesis $H_{1}: s_{1}^{2} \neq s_{2}^{2}$. Subsequently, we will establish the zero hypothesis $H_{0}: m_{1}=m_{2}$ and the alternative hypothesis $H_{1}: m_{1}>m_{2}$, which expresses the fact that the first set of companies with a higher share of positive posts also has a higher average difference in stock prices $m_{1}$ than second set of companies $m_{2}$. Using the t-test with test criterion (1) with the equality of variances, where $m$ denotes 


\section{Tab. 2: List of companies}

\begin{tabular}{|c|c|c|c|c|c|c|c|c|c|}
\hline \multirow[t]{2}{*}{ Company name } & \multirow[t]{2}{*}{ Segment } & \multicolumn{4}{|c|}{$\begin{array}{l}\text { Changes in the stock prices } \\
\text { (Q2 2018 - Q1 2019) }\end{array}$} & \multicolumn{4}{|c|}{$\begin{array}{l}\text { Share of positive posts } \\
\text { compared to negative ones } \\
\text { (Q2 2018 - Q1 2019) }\end{array}$} \\
\hline & & Q2 & Q3 & Q4 & Q1 & Q2 & Q3 & Q4 & Q1 \\
\hline $3 M$ & $\mathrm{~B} 2 \mathrm{~B}$ & $-10 \%$ & $8 \%$ & $-11 \%$ & $10 \%$ & $79 \%$ & $72 \%$ & $64 \%$ & $70 \%$ \\
\hline American Express & $\mathrm{B} 2 \mathrm{C}$ & $5 \%$ & $9 \%$ & $-11 \%$ & $16 \%$ & $84 \%$ & $61 \%$ & $60 \%$ & $68 \%$ \\
\hline Apple & $\mathrm{B} 2 \mathrm{C}$ & $10 \%$ & $22 \%$ & $-31 \%$ & $22 \%$ & $79 \%$ & $79 \%$ & $62 \%$ & $74 \%$ \\
\hline Boeing & $\mathrm{B} 2 \mathrm{~B}$ & $2 \%$ & $11 \%$ & $-15 \%$ & $21 \%$ & $71 \%$ & $69 \%$ & $61 \%$ & $59 \%$ \\
\hline Caterpillar & $\mathrm{B} 2 \mathrm{~B}$ & $-8 \%$ & $12 \%$ & $-18 \%$ & $8 \%$ & $78 \%$ & $75 \%$ & $77 \%$ & $77 \%$ \\
\hline Cisco & B2B & $0 \%$ & $13 \%$ & $-12 \%$ & $26 \%$ & $76 \%$ & $31 \%$ & $74 \%$ & $75 \%$ \\
\hline Coca-Cola & $\mathrm{B} 2 \mathrm{C}$ & $1 \%$ & $5 \%$ & $2 \%$ & $-1 \%$ & $78 \%$ & $70 \%$ & $79 \%$ & $75 \%$ \\
\hline Disney & $\mathrm{B} 2 \mathrm{C}$ & $4 \%$ & $12 \%$ & $-8 \%$ & $3 \%$ & $80 \%$ & $80 \%$ & $69 \%$ & $70 \%$ \\
\hline DowDuPont Inc. & $\mathrm{B} 2 \mathrm{~B}$ & $3 \%$ & $-2 \%$ & $-18 \%$ & $1 \%$ & $73 \%$ & $58 \%$ & $55 \%$ & $47 \%$ \\
\hline Exxon Mobil & $\mathrm{B} 2 \mathrm{~B}$ & $11 \%$ & $3 \%$ & $-20 \%$ & $19 \%$ & $78 \%$ & $88 \%$ & $60 \%$ & $46 \%$ \\
\hline Goldman Sachs & $\mathrm{B} 2 \mathrm{~B}$ & $-7 \%$ & $-4 \%$ & $-27 \%$ & $18 \%$ & $62 \%$ & $67 \%$ & $40 \%$ & $53 \%$ \\
\hline Home Depot & $\mathrm{B} 2 \mathrm{C}$ & $9 \%$ & $6 \%$ & $-18 \%$ & $13 \%$ & $78 \%$ & $61 \%$ & $60 \%$ & $68 \%$ \\
\hline Chevron & B2B & $11 \%$ & $-3 \%$ & $-11 \%$ & $13 \%$ & $76 \%$ & $82 \%$ & $72 \%$ & $77 \%$ \\
\hline IBM & B2B & $-9 \%$ & $8 \%$ & $-25 \%$ & $25 \%$ & $82 \%$ & $79 \%$ & $76 \%$ & $76 \%$ \\
\hline Intel & $\mathrm{B} 2 \mathrm{C}$ & $-5 \%$ & $-3 \%$ & $-3 \%$ & $15 \%$ & $67 \%$ & $61 \%$ & $65 \%$ & $59 \%$ \\
\hline Johnson \& Johnson & $\mathrm{B} 2 \mathrm{C}$ & $-5 \%$ & $14 \%$ & $-8 \%$ & $10 \%$ & $74 \%$ & $69 \%$ & $67 \%$ & $71 \%$ \\
\hline JPMorgan Chase & $\mathrm{B} 2 \mathrm{~B}$ & $-5 \%$ & $8 \%$ & $-14 \%$ & $5 \%$ & $75 \%$ & $57 \%$ & $51 \%$ & $55 \%$ \\
\hline McDonald's & $\mathrm{B} 2 \mathrm{C}$ & $0 \%$ & $7 \%$ & $5 \%$ & $8 \%$ & $74 \%$ & $70 \%$ & $73 \%$ & $65 \%$ \\
\hline Merck & B2B & $11 \%$ & $17 \%$ & $6 \%$ & $10 \%$ & $67 \%$ & $67 \%$ & $84 \%$ & $83 \%$ \\
\hline Microsoft & $\mathrm{B} 2 \mathrm{C}$ & $8 \%$ & $16 \%$ & $-12 \%$ & $17 \%$ & $74 \%$ & $75 \%$ & $70 \%$ & $74 \%$ \\
\hline Nike & $\mathrm{B} 2 \mathrm{C}$ & $20 \%$ & $6 \%$ & $-13 \%$ & $15 \%$ & $77 \%$ & $79 \%$ & $73 \%$ & $84 \%$ \\
\hline Pfizer & B2C & $2 \%$ & $21 \%$ & $-3 \%$ & $-1 \%$ & $65 \%$ & $75 \%$ & $71 \%$ & $55 \%$ \\
\hline Procter \& Gamble & $\mathrm{B} 2 \mathrm{C}$ & $-2 \%$ & $7 \%$ & $10 \%$ & $14 \%$ & $65 \%$ & $71 \%$ & $83 \%$ & $82 \%$ \\
\hline $\begin{array}{l}\text { Travelers } \\
\text { Companies Inc. }\end{array}$ & B2B & $-12 \%$ & $6 \%$ & $-9 \%$ & $16 \%$ & $84 \%$ & $74 \%$ & $85 \%$ & $84 \%$ \\
\hline $\begin{array}{l}\text { United } \\
\text { Technologies }\end{array}$ & B2C & $-1 \%$ & $12 \%$ & $-25 \%$ & $22 \%$ & $80 \%$ & $79 \%$ & $73 \%$ & $80 \%$ \\
\hline UnitedHealth & $\mathrm{B} 2 \mathrm{C}$ & $15 \%$ & $8 \%$ & $-7 \%$ & $0 \%$ & $92 \%$ & $63 \%$ & $61 \%$ & $56 \%$ \\
\hline Verizon & $\mathrm{B} 2 \mathrm{C}$ & $5 \%$ & $6 \%$ & $4 \%$ & $7 \%$ & $79 \%$ & $62 \%$ & $65 \%$ & $60 \%$ \\
\hline Visa & $\mathrm{B} 2 \mathrm{C}$ & $11 \%$ & $13 \%$ & $25 \%$ & $19 \%$ & $79 \%$ & $77 \%$ & $77 \%$ & $74 \%$ \\
\hline Walgreen & $\mathrm{B} 2 \mathrm{C}$ & $-8 \%$ & $21 \%$ & $-7 \%$ & $-7 \%$ & $62 \%$ & $69 \%$ & $69 \%$ & $65 \%$ \\
\hline Wal-Mart & B2C & $-4 \%$ & $10 \%$ & $-2 \%$ & $6 \%$ & $75 \%$ & $71 \%$ & $72 \%$ & $59 \%$ \\
\hline
\end{tabular}

Source: Unamo (2019), SPIndices.com (2019), the division into B2B and B2C is based on the prevalent type of the companies' customers (most companies operate on both markets) 
the calculated differences in stock prices and $n$ denotes the number of values in the respective selections, we will examine whether the percentage difference in stock prices in the given period exhibits a significant statistical difference between the two sets of companies.

$$
T=\frac{m_{1}-m_{2}}{\sqrt{n_{1} \times s_{1}^{2}+n_{2} \times s_{2}^{2}}} \times \sqrt{\frac{n_{1} \times n_{2} \times\left(n_{1}+n_{2}-2\right)}{n_{1}+n_{2}}}
$$

The so-called $p$-value will be used in the testing. The $p$-value is the significance level for this test. It is the smallest level of significance alpha at which the hypothesis $H_{0}$ can still be rejected.

The analysis will be conducted separately for companies operating primarily on the B2C and B2B market. This will allow us to discuss the differences between the two types of companies.

Analysis 2) How much of companies' website traffic is routed through eWOM on social media sites? Applying the Similarweb. com tool to the tested sample, we will establish the amount of traffic on the companies' websites coming from social media sites. The tool Similarweb.com (2017) is recommended for website traffic analyses by Fishkin (2015), who tested the quality of this tool on 143 websites that have between thousands to as many as millions of visitors monthly. We will examine the percentage share of website traffic routed through social media sites in relation to their total website traffic. To test the similarity of the values throughout the sample, we will compute the variance variable.

Analysis 3) Through which social media sites does eWOM attract the most traffic to companies' websites? This analysis is related to the previous research question. We will establish which social media sites attract users to visit the companies' websites, and thus are most important for companies in this respect, and what significance they can have for companies. The share of individual social media sites in the total website traffic routed through social media will be expressed in percentage points.

\section{Results}

Question 1) based on our results, eWOM can serve as an indicator of companies' performance, measured in terms of stockvalue change. We found relationship between social media posts and change in stock prices, meaning that changes of stock prices were reflected on social media. This was only proven for companies operating in the B2C segment (Hypothesis 1 - Tab. 3). Companies that saw a higher share of positive posts exhibited a higher increase in their stock prices in the same time period. The $p$-value for the t-test was below 0.01 for all tested quarters. The zero hypothesis at 0.01 significance level is thus rejected in favor of the alternative hypothesis, which means that the first set of companies with the higher share of positive posts compared to negative ones also saw a higher average increase in stock prices. On the other hand, at companies operating in the B2B segment, the sentiment of social media posts was not found to have an effect on their stock prices (Hypothesis 2 - Tab. 4). The p-value of the t-test was above 0.1 for all tested quarters.

High quarter increase in stock prices of companies in the given sample was seen in the companies Visa and Microsoft (above $+10 \%$ ). Both these companies also had a high average of positive-to-negative social media post ratio (Visa $77 \%$, Microsoft $73 \%$ ). At the other end of the spectrum, one of the weakest performance

\section{Tab. 3: T-test results for B2C companies (Hypothesis 1)}

\begin{tabular}{l|c|c|l|c}
\multicolumn{1}{c|}{ Period } & Test criterion (T) & Critical region & P-value & Result \\
\hline Q2 2018 & 3.25 & $>1.75$ & 0.002 & $\mathrm{H}_{0}$ is rejected \\
\hline Q3 2018 & 4.35 & $>1.75$ & 0.00001 & $\mathrm{H}_{0}$ is rejected \\
\hline Q4 2018 & 2.66 & $>1.75$ & 0.009 & $\mathrm{H}_{0}$ is rejected \\
\hline Q1 2019 & 2.84 & $>1.75$ & 0.006 & $\mathrm{H}_{0}$ is rejected \\
\hline Whole period & 5.94 & $>1.67$ & 0.00001 & $\mathrm{H}_{0}$ is rejected \\
\hline
\end{tabular}

Source: own, tested at 0.01 alpha level of significance 
Tab. 4: T-test results for B2B companies (Hypothesis 2)

\begin{tabular}{l|c|c|c|c}
\multicolumn{1}{c|}{ Period } & Test criterion (T) & Critical region & P-value & Result \\
\hline Q2 2018 & -0.83 & $>1.81$ & 0.787 & $\mathrm{H}_{0}$ is not rejected \\
\hline Q3 2018 & -1.25 & $>1.81$ & 0.880 & $\mathrm{H}_{0}$ is not rejected \\
\hline Q4 2018 & 1.31 & $>1.81$ & 0.109 & $\mathrm{H}_{0}$ is not rejected \\
\hline Q1 2019 & -0.29 & $>1.81$ & 0.612 & $\mathrm{H}_{0}$ is not rejected \\
\hline Whole period & -0.39 & $>1.68$ & 0.650 & $\mathrm{H}_{0}$ is not rejected \\
\hline
\end{tabular}

Source: own, tested at 0.01 alpha level of significance

within the sample was that of the company Goldman Sachs. This coincides with the prevailing negative posts about this company. Intel's positive-to-negative social media post ratio during the test period even drop to $40 \%$. Also Intel has low positive-to-negative social media post ratio as the company experiencing problems related to their processors and their security, which was discussed not only in the mainstream media, but also by users themselves on social media.

The close connection between the development of stock shares and the responses on social media is well evident in Apple's stock development. Significant growth and a high share of positive posts compared to negative ones from Q2 to Q3 2018 was replaced by a drop in share prices in Q4 2018, which was accompanied by decline in the share of positive posts compared to negative ones (Q3 $201879 \%$, Q4 2018 only $62 \%$ ).

We also calculated correlations using the Pearson correlation coefficent between the two mentioned variables - changes in stock prices and share of positive to negative post ratio. The data for calculations can be seen in Tab. 2 . Significance level of the test was 0.05 .

The test showed a positive significant correlation between the analyzed variables for B2C companies in all four quarters. On the other hand, we have not found significant correlation between the analyzed variables for B2B companies in all quarters (only significant correlation was found in Q4). The results are shown in Tab. 5.

Question 2) The websites of companies included in the US30 stock market index saw a combined traffic of over 25 billion visits during the selected period from Q2 2018 to Q1 2019 (microsoft.com had the most website traffic). Social media brought on average only about $3 \%$ of the total website traffic to the websites of companies listed in the US30 index (Tab. 6). Social media sites try to keep users on their sites because they want to show users more advertisements to have higher profits. This value is similar throughout the sample with the variance in values being only 5 . The maximum value in the tested sample reached $11 \%$ for exxonmobil.com and the minimum value reached $0.3 \%$ for dow-dupont.com. Social media bring much less traffic to the companies' websites than search engines (40\%) and direct visits (39\%).

Question 3) The most traffic from social media to the websites of US30 companies comes from Facebook (Tab. 7). An average of $25 \%$ of website traffic was routed through YouTube and $17 \%$ through Linkedln. On the other hand, the social media sites Pinterest

\section{Tab. 5: Pearson correlation results for B2C and B2B companies}

\begin{tabular}{c|c|c|c|c}
\multirow{2}{*}{ Type of companies } & \multicolumn{4}{|c}{ Pearson correlation coeficient } \\
\cline { 2 - 5 } & $\mathbf{Q 2}$ & $\mathbf{Q 3}$ & $\mathbf{Q 4}$ & $\mathbf{Q 1}$ \\
\hline$B 2 C(\mathrm{R}>0.468, \mathrm{n}=18)$ & $\mathbf{0 . 6 2 8}$ & $\mathbf{0 . 5 1 6}$ & $\mathbf{0 . 5 6 0}$ & $\mathbf{0 . 5 6 7}$ \\
\hline$B 2 B(\mathrm{R}>0.576, \mathrm{n}=12)$ & -0.331 & 0.291 & $\mathbf{0 . 5 8 4}$ & 0.235 \\
\hline
\end{tabular}

Source: own, tested at 0.05 alpha level of significance 
Tab. 6: The source of traffic to the websites of companies listed in the US30 index

\begin{tabular}{l|c|c}
\multicolumn{1}{c|}{ Sources of website traffic } & $\begin{array}{c}\text { Average share of website traffic } \\
\text { from the particular source }\end{array}$ & Variance $\left(\boldsymbol{\sigma}^{\mathbf{2}}\right)$ \\
\hline Search engines & $40 \%$ & 262 \\
\hline Direct & $39 \%$ & 160 \\
\hline Referrals & $11 \%$ & 80 \\
\hline Social media & $3 \%$ & 5 \\
\hline Others & $5 \%$ & 7 \\
\hline
\end{tabular}

Source: own

\begin{tabular}{|c|c|c|}
\hline $\begin{array}{l}\text { Tab. 7: } \begin{array}{l}\text { A list of socia } \\
\text { to US30 comp }\end{array}\end{array}$ & $\begin{array}{l}\text { sites through which the most w } \\
\text { websites }\end{array}$ & raffic is routed \\
\hline Social media site & $\begin{array}{l}\text { Average share of social website } \\
\text { traffic coming from the particular } \\
\text { social media site }\end{array}$ & Variance $\left(\sigma^{2}\right)$ \\
\hline Facebook & $34 \%$ & 242 \\
\hline YouTube & $25 \%$ & 173 \\
\hline Linkedln & $17 \%$ & 340 \\
\hline Reddit & $7 \%$ & 45 \\
\hline Twitter & $6 \%$ & 37 \\
\hline Pinterest & $3 \%$ & 8 \\
\hline Instagram & $3 \%$ & 8 \\
\hline Others & $5 \%$ & 15 \\
\hline
\end{tabular}

Source: own

and Instagram do not bring too much traffic to companies' websites. The purpose of both these social media sites is to share photos and the ability to add hyperlinks is very limited.

The social media site Linkedln exhibits a distinct variance throughout the sample, which is caused by the different functions of some websites within the sample. For example, the website apple.com aims to offer the company's products, while the purpose of chevron.com is to attract new staff to the company. As a result, the percentage of website traffic to apple.com from Linkedln is only $1 \%$, while it is as high as $56 \%$ in the case of chevron.com.

Users themselves most frequently mention companies on Facebook. Up to $88 \%$ of all analyzed posts mentioning the names of US30 companies appeared on Facebook. Seven percent of posts were on YouTube. A large number of posts mentioning the companies on Facebook appeared as part of posts by news agencies. Such posts then generate website traffic as shown in Tab. 5. The share of Twitter and Instagram posts mentioning the names of US30 companies was below $5 \%$. Due to the absence of API, content of the posts on the social media sites LinkedIn, Reddit and Pinterest were not analyzed.

\section{Conclusions}

Users actively discuss the companies that make up the US30 stock market index on social media. A relationship between social media posts and change in stock prices was found, meaning that changes of stock prices were reflected on social media. This means, from the perspective of our paper, that eWOM can serve as an indicator of companies' performance. The relationship between the posts spread by eWOM and change in stock value was statistically significant in companies operating in the B2C segment. Companies in the B2C 
segment reached higher stock market prices if they exhibit a higher share of positive posts on social media compared to negative ones. These findings are in line with the studies conducted by Li et al. 2017; Nguyen et al. 2015; Oliveira et al. 2017. They further stated that stock market development can be predicted based on social media posts. However, none of the aforementioned studies deals with companies in the B2B segment, where our research revealed that the sentiment spread through eWOM on social media does not affect the companies' value on the stock market.

Three percent of the total visitor traffic is brought to the companies' websites through eWOM shared on social media sites. It needs to be noted that part of the website traffic generated through eWOM may be included in direct visits to websites or those coming from search engines, which are the major source of visitor traffic. An example of such a situation would be someone reading a social media post about a particular company and then looking it up using a search engine. Social media sites often deliberately try to prevent people from leaving their site for another website, which may result in a loss of profit from advertising for the particular social media platform. In connection with this issue, Sabate (2014) and Tikno (2017) note that Facebook gives priority to posts containing images or videos over those with hyperlinks.

The most significant social media sites in terms of visitor traffic to the websites of US30 companies are Facebook, YouTube and Linkedln. As much as $88 \%$ of all the analyzed posts from the social media sites Facebook, YouTube, Twitter and Instagram appeared on Facebook. Only a negligible part of these posts were created by the companies themselves. A different situation is found with Linkedln, where the majority of the content about companies is generated by the companies themselves.

Based on the research findings, eWOM can be considered to be of significance for companies in the B2C segment, where it can serve as an indicator of performance. These findings are in line with studies presented in the literature review, e.g. Nieto et al. (2014) and Tajvidi and Karami (2017). This conclusion can be useful in predicting particular companies' stock prices based on eWOM. The advantage is that information on social media posts can be obtained in real time and thus can capture even short-term (over a period of several months) developments in prices on the stock market. Based on the financial performance of the given companies, it is possible to determine more accurately which companies will most likely do better in the future.

\section{Limitations and Further Research}

The present study has several limitations. First limitation of the research lies in the fact that it was conducted on a sample of large companies. Generalizing these findings to companies of a different size could be misleading. Second, the research sample consisted of large joint-stock companies located in the USA. Generalizing the findings to other joint-stock companies located outside of the USA could again be misleading. Third, the analysis covered relatively small sample of companies. Expansion of a sample could bring more reliable results. Any further research may include other companies from other regions and also discuss differences in the use of social media across the market and countries. Because the aim of our research was mainly to prove or deny the connection between eWOM and companies performance, future research can go further and closely evaluate the extent of this connection between eWOM and financial results of $\mathrm{B} 2 \mathrm{C}$ companies. A downside of this research is the fact that the credibility of the posts' authors was not evaluated, as suggested by Ruan, Durresi and Alfantoukh (2018).

\section{References}

Brown, J., Broderick, A. J., \& Lee, N. (2007). Word of mouth communication within online communities: Conceptualizing the online social network. Journal of Interactive Marketing, 21, 2-20. https://doi.org/10.1002/dir.20082.

Carl, W. J. (2006). Whats All The Buzz about?: Everyday Communication and the Relational Basis of Word-of-Mouth and Buzz Marketing Practices. Management Communication Quarterly, 19, 601-634. https://doi.org/10.1177/0893318905284763.

Colquitt, J. A., Scott, B. A., \& LePine, J. A. (2007). Trust, trustworthiness, and trust propensity: a meta-analytic test of their unique relationships with risk taking and job performance. Journal of applied psychology, 92(4), 909-927.

Coombs, A. (2017). Understanding Sentiment Analysis in Social Media Monitoring. 
Retrieved May 12, 2019, from https://unamo. $\mathrm{com} / \mathrm{blog} / \mathrm{social} / \mathrm{sentiment-analysis-social-}$ media-monitoring.

Daugherty, T., \& Hoffman, E. (2014). eWOM and the importance of capturing consumer attention within social media. Journal of Marketing Communications, 20, 82-102. https://doi.org/10.1080/13527266.2013.797764.

Duan, W., Gu, B., \& Whinston, A. B. (2008). The dynamics of online word-of-mouth and product sales - An empirical investigation of the movie industry. Journal of Retailing, 84, 233-242. https://doi.org/10.1016/j.jretai.2008.04.005.

Eger, L., Mičík, M., \& Řehoř, P. (2018). Employer branding on social media and recruitment websites: Symbolic traits of an ideal employer. E\&M Ekonomie a Management, 21(1), 224-237. https://dx.doi.org/10.15240/ tul/001/2018-1-015.

Fishkin, R. (2015). The Traffic Prediction Accuracy of 12 Metrics from Compete, Alexa, SimilarWeb, \& More. Retrieved May 12, 2019, from https://sparktoro.com/blog/trafficprediction-accuracy-12-metrics-competealexa-similarweb/.

Geurin, A. N., \& Burch, L. M. (2017). User-generated branding via social media: An examination of six running brands. Sport Management Review, 20, 273-284. https://doi. org/10.1016/j.smr.2016.09.001.

Godey, B., Manthiou, A., Pederzoli, D., Rokka, J., Aiello, G., Donvito, R., \& Singh, R. (2016). Social media marketing efforts of luxury brands: Influence on brand equity and consumer behavior. Journal of Business Research, 69, 5833-5841. https://doi.org/10.1016/j.jbusres.2016.04.181.

Grizane, T., \& Jurgelane, I. (2017). Social Media Impact on Business Evaluation. Procedia Computer Science, 104, 190-196. https://doi. org/10.1016/j.procs.2017.01.103.

Huete-Alcocer, N. (2017). A Literature Review of Word of Mouth and Electronic Word of Mouth: Implications for Consumer Behavior. Frontiers in Psychology, 8, 1256. https://doi. org/10.3389/fpsyg.2017.01256.

Hughes, M. (2005). Buzzmarketing: Get People to Talk About Your Stuff. London: Penguin Publishing Group.

Hussain, S., Ahmed, W., Jafar, R. M., Rabnawaz, A., \& Jianzhou, Y. (2017). eWOM source credibility, perceived risk and food product customers information adoption. Computers in Human Behavior, 66, 96-102. https://doi.org/10.1016/j.chb.2016.09.034.
Charoensukmongkol, P., \& Sasatanun, P. (2017). Social media use for CRM and business performance satisfaction: The moderating roles of social skills and social media sales intensity. Asia Pacific Management Review, 22, 25-34. https://doi.org/10.1016/j. apmrv.2016.10.005.

Choi, B., \& Lee, I. (2017). Trust in open versus closed social media: The relative influence of user- and marketer-generated content in social network services on customer trust. Telematics and Informatics, 34, 550-559. https://doi.org/10.1016/j.tele.2016.11.005.

Kaushik, B., Hemani, H., \& Ilavarasan, P. V. (2017). Social media usage vs. stock prices: an analysis of Indian firms. Procedia Computer Science, 122, 323-330. https://doi. org/10.1016/j.procs.2017.11.376.

Kim, S., Koh, Y., Cha, J., \& Lee, S. (2015). Effects of social media on firm value for U.S. restaurant companies. International Journal of Hospitality Management, 49, 40-46. https://doi. org/10.1016/j.ijhm.2015.05.006.

Kotler, P., \& Keller, K. L. (2013). Marketing management. Prague: Grada.

Lee, M., \& Youn, S. (2009). Electronic word of mouth (eWOM). International Journal of Advertising, 28, 473-499. https://doi. org/10.2501/S0265048709200709.

Li, B., Chan, K. C., Ou, C., \& Ruifeng, S. (2017). Discovering public sentiment in social media for predicting stock movement of publicly listed companies. Information Systems, 69, 81-92. https://doi.org/10.1016/j.is.2016.10.001.

Litvin, S. W., Goldsmith, R. E., \& Pan, B. (2008). Electronic word-of-mouth in hospitality and tourism management. Tourism Management, 29, 458-468. https://doi. org/10.1016/j.tourman.2007.05.011.

Marine-Roig, E., \& Clavé, S. A. (2015). Tourism analytics with massive user-generated content: A case study of Barcelona. Journal of Destination Marketing \& Management, 4, 162-172. https://doi.org/10.1016/j. jdmm.2015.06.004.

Mayer, R. C., Davis, J. H., \& Schoorman, F. D. (1995). An Integrative Model of Organizational Trust. The Academy of Management Review, 20(3), 709-734.

Nascimento, A. M., \& da Silveira, D. S. (2017). A systematic mapping study on using social media for business process improvement. Computers in Human Behavior, 73, 670-675. https://doi.org/10.1016/j.chb.2016.10.016. 
Nguyen, T. H., Shirai, K., \& Velcin, J. (2015). Sentiment analysis on social media for stock movement prediction. Expert Systems with Applications, 42, 9603-9611. https://doi. org/10.1016/j.eswa.2015.07.052.

Nieto, J., Hernández-Maestro, R. M., \& Muñoz-Gallego, P. A. (2014). Marketing decisions, customer reviews, and business performance: The use of the Toprural website by Spanish rural lodging establishments. Tourism Management, 45, 115-123. https://doi. org/10.1016/j.tourman.2014.03.009.

Oliveira, N., Cortez, P., \& Areal, N. (2017). The impact of microblogging data for stock market prediction: Using Twitter to predict returns, volatility, trading volume and survey sentiment indices. Expert Systems with Applications, 73, 125-144. https://doi. org/10.1016/j.eswa.2016.12.036.

Ruan, Y., Durresi, A., \& Alfantoukh, L. (2018). Using Twitter trust network for stock market analysis. Knowledge-Based Systems, 145, 207-218. https://doi.org/10.1016/j. knosys.2018.01.016.

Sedlačík, M., Neubauer, J., \& Kříž, O. (2016). Základy statistiky: Aplikace $v$ technických a ekonomických oborech - 2. vydání. Prague: Grada.

SimilarWeb. (2017). How Does SimilarWeb Work? Retrieved May 12, 2019, from https://www.similarweb.com/ourdata.

SPIndices.com. (2018). Our Company S\&P Dow Jones Indices. Retrieved May 12, 2019, from https://www.spindices.com/ourcompany/our-history/.

Tajvidi, R., \& Karami, A. (2017). The effect of social media on firm performance. Computers in Human Behavior. Article in Press. https://doi. org/10.1016/j.chb.2017.09.026.

Unamo.com. (2018). Unamo: Tools for Marketers. Retrieved May 12, 2019, from https://unamo.com.
Vendemia, M. A. (2017). When do consumers buy the company? Perceptions of interactivity in company-consumer interactions on social networking sites. Computers in Human Behavior, 71, 99-109. https://doi.org/10.1016/j. chb.2017.01.046.

Wang, T., Yeh, R. K.-J., Chen, C., \& Tsydypov, Z. (2016). What drives electronic word-of-mouth on social networking sites? Perspectives of social capital and selfdetermination. Telematics and Informatics, 33, 1034-1047. https://doi.org/10.1016/j. tele.2016.03.005.

Wilson, S. (2010). Social Media and Small Business Marketing. Raleigh, NC: Lulu Enterprises Incorporated.

Yadav, M., \& Rahman, Z. (2017). Measuring consumer perception of social media marketing activities in e-commerce industry: Scale development \& validation. Telematics and Informatics, 34, 1294-1307. https://doi. org/10.1016/j.tele.2017.06.001.

Yang, F. X. (2017). Effects of Restaurant Satisfaction and Knowledge Sharing Motivation on eWOM Intentions: The Moderating Role of Technology Acceptance Factors. Journal of Hospitality \& Tourism Research, 41, 93-127. https://doi.org/10.1177/1096348013515918.

Ing. David Prantl University of West Bohemia Faculty of Economics Department of Marketing, Trade and Services Czech Republic prantld@kmo.zcu.cz

Ing. Michal Mičík, Ph.D. University of West Bohemia Faculty of Economics Department of Marketing, Trade and Services Czech Republic micikm@kmo.zcu.cz 


\section{Abstract}

\section{ANALYSIS OF THE SIGNIFICANCE OF EWOM ON SOCIAL MEDIA FOR COMPANIES}

\section{David Prantl, Michal Mičík}

In recent years, social media have changed online communication. People share their views on individual companies as well as reviews of various products, and actively engage in discussions. Communication that spreads in this way is referred to as eWOM. The question is how important eWOM on social media can be for companies and what we can conclude based on eWOM. This research study aims to evaluate the significance of eWOM for companies in terms of the connection between eWOM and stock prices. Further, we explore the impact of eWOM on company website traffic. The research was conducted using a sample of 1,420,000 posts on social media sites mentioning companies that make up the components of the US30 stock market index. The results show that companies in the B2C segment with a higher share of positive posts compared to negative ones have seen a greater increase in stock prices. However, posts on social media mentioning companies in the B2B segment are not connected to the movement of stock prices of these companies. The research also revealed that $3 \%$ of the total traffic on companies' websites comes from social media sites. Based on the findings of the research, we can consider eWOM to be of major significance for companies in the B2C segment. These conclusions can be useful in predicting stock prices of particular companies on stock markets based on eWOM.

Keywords: eWOM, stocks, sentiment, social media.

JEL Classification: M31.

DOI: 10.15240/tul/001/2019-4-012. 